\section{ANALISIS PENERAPAN AKUNTANSI DANA ZAKAT DAN INFAK/SEDEKAH PADA LEMBAGA AMIL ZAKAT INFAK, DAN SHODAQOH MUHAMMADIYAH (LAZISMU) KABUPATEN MALANG}

\author{
Rita Anggun Pertiwi, Masiyah Kholmi, Eris Tri Kurniawati \\ Program Sarjana Universitas Muhammadiyah Malang \\ Fakultas Ekonomi dan Bisnis Universitas Muhammadiyah Malang \\ Email: Maisyah.umm.@gmail.com
}

JRAK

\title{
Abstract
}

The purpose of this study is to analyze the application of zakat fund accounting at LAZISMU Malang Regency. Analytical technique is done by using case study research to see the suitability of accounting application. the results obtained by this research in general accounting treatment of zakat by LAZISMU Malang Regency is good enough that includes recognition and distribution. However, measurement, presentation and disclosure are not in accordance with PSAK 109.besides, there is no separation between zakat fund and amil fund.

Keywords: PSAK 109, zakat fund accounting

\section{PENDAHULUAN}

Zakat adalah harta yang wajib dikeluarkan oleh umat Islam sesuai dengan ketentuan syariah untuk diberikan kepada yang berhak menerimanya (mustahiq). Dalam hal ini mengeluarkan/membayar zakat adalah kewajiban bagi setiap orang yang beragama Islam sebagai penyucian jiwa Mu'is (2011). Kewajiban zakat merupakan sebuah kewajiban yang menghasilkan hikmah bagi pemerataan pendapatan pada suatu negara termasuk Indonesia.

Secara demografik penduduk Indonesia mayoritas beragama Islam. Menurut Kajian Islam Online yang dimuat dalam berita Info Jambi menyebutkan bahwa populasi muslim di Indonesia sekarang sudah mencapai $87 \%$ dari keseluruhan populasi penduduk Indonesia. Ketika penduduk Islam semakin banyak maka penghimpunan dan penyaluran zakat juga semakin meningkat. Hal ini dikuatkan dengan data Badan Amil Zakat Nasional (BAZNAS) yang menunjukkan bahwa penerimaan zakat dari tahun ke tahun semakin meningkat mencapai $\mathrm{Rp}$ 73.714.349.078, 00 per September 2015. (BAZNAS 2015).

Berdasarkan Bab III Undang-Undang (UU) No. 38 tahun 1999, Penghimpunan dan penyaluran zakat dan infak/sedekah di Indonesia diamanahkan kepada organisasi pengelola zakat (OPZ) yang terdiri dari dua jenis, yaitu Badan Amil Zakat (pasal 6) yang dibentuk oleh pemerintah Lembaga Amil Zakat (pasal 7) yang dibentuk oleh masyarakat. Baik Badan Amil Zakat (BAZ) maupun Lembaga Amil Zakat (LAZ) diperinci dalam UU 23 tahun 2011.

Posisi amil (pengelola zakat) yang diformulasikan dalam bentuk LAZ dan BAZ merupakan lembaga kepercayaan publik yang sensitif dalam menghimpun dan menyalurkan dana-dana zakat. Namun terdapat ketidakpercayaan oleh pembayar zakat (Muzakki) disebabkan belum transparansinya laporan penggunaan

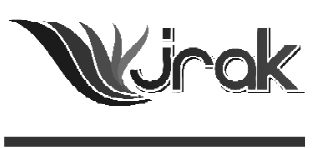

Jurnal Reviu Akuntansi dan Keuangan ISSN: 2088-0685 Vol.5 No. 2, Oktober 2015 Pp 751-758 
Analisis

Penerapan

Akuntansi...

752 dana zakat Organisasi Pengelola Zakat (OPZ). Karena itu aturan pelaporan penggunaan dana zakat wajib diberlakukan oleh semua Amil di Indonesia (Nikmatuniayah, 2012). Hasil penelitian menunjukkan bahwa kredibilitas lembaga amil zakat berpengaruh positif dan signifikan terhadap motivasi membayar zakat, (Kanji dan Habbe 2011).

Oleh sebab itu, OPZ perlu menerapkan akuntabilitas dan transparansi dalam pengelolaan dana zakat dengan menerapkan akuntansi zakat dan infak/sedekah. Ikatan Akuntan Indonesia (IAI) telah menerbitkan standar pengelolaan keuangan atas dana zakat dan infak/sedekah (ZIS) berupa Pernyataan Standar Akuntansi Keuangan (PSAK) 109 yang secara rinci membahas panduan Akuntansi dana ZIS meliputi proses pengakuan, pengukuran, penyajian, dan pengungkapan transaksi zakat, infak/sedekah sesuai dengan kaedah syariat Islam. PSAK 109 ini sangat penting diterapkan dalam pengelolaan dana zakat, karena OPZ mengelola dana masyarakat sehingga dana tersebut harus dikelola secara terpercaya dan sesuai standar serta dilaporkan secara transparan kepada masyarakat.

Salah satu Lembaga Amil Zakat (LAZ) nasional di Indonesia yang berperan dalam pengelolaan dana zakat secara profesional adalah Lembaga Amil Zakat Infak dan Shodaqah Muhamadiyah (LAZISMU). Hingga saat ini jumlah LAZISMU telah mencapai 103 jejaring termasuk LAZISMU kabupaten Malang. Di Malang sendiri terdapat banyak lembaga amil zakat. Muhammadiyah mempunyai dua LAZIS yaitu LAZISMU kabupaten dan LAZISMU kota Malang. LAZISMU kabupaten Malang telah menjangkau masyarakat kota maupun pedalaman yang berada di Kabupaten dan kecamatan-kecamatan yang berada dalam naungan Pimpinan Daerah Muhammadiyah Kabupaten Malang. Sudah memiliki program rutin beasiswa sekolah serta sudah mempunyai jaringan kerjasama dengan berbagai organisasi untuk dalam menyalurkan zakat infak dan sedekah.

Menurut data statistik PDM Kabupaten Malang, LAZISMU kabupaten Malang menaungi 26 cabang dan 143 Ranting. Dengan banyaknya cabang dan ranting LAZISMU tersebut maka potensi dana ZIS yang dikelola semakin meningkat tiap periode. Berdasarkan data laporan keuangan LAZISMU yang terpublikasikan dalam buletin "Matahati" pada bulan november dana yang diterima dan dikelola oleh LAZISMU sejumlah Rp. 23.980.800, 00. Diharapkan dengan semakin luasnya daerah jangkauan dan banyaknya dana yang dikelola tersebut Sumber daya Manusia yang meliputi pengurus dan staff LAZISMU dapat memahami konsep dan teknik pengelolaan dana ZIS yang sesuai dengan standar yang ditetapkan oleh IAI dan diberlakukan oleh BAZNAS yaitu PSAK 109 sebagaimana yang telah dipaparkan diatas. Oleh sebab itu, LAZISMU harus menerapakan PSAK 109 ini baik dari pencatatan dana masuk dan dana keluarkan sampai tahap pelaporan dana. Sehingga, masyarakat dapat mengetahui berapa dana yang diterima LAZISMU dan untuk siapa LAZISMU menyalurkan dana ZIS tersebut dapat meningkatkan kinerjanya dan dapat melaksanakan pengelolaan dana zakat dari waktu ke waktu secara akuntabel.

Penelitian tentang penerapan akuntansi zakat telah banyak dilakukan seperti Istutik (2013) yang membuktikan bahwa penerapan akuntansi zakat pada OPZ yang belum sesuai dengan PSAK 109. Sedangkan penelitian Handoko (2013) menyatakan bahwa penerapan akuntansi zakat pada yayasan Dompet Dhuafa Republika secara keseluruhan telah menerapkan PSAK 109. Berdasarkan uraian latar belakang dan ketidak-konsistenan hasil penelitian diatas, maka peneliti tertarik untuk melakukan penelitian untuk menganalisis sejauh mana penerapan PSAK 109 mengenai akuntansi dana zakat dan infak/sedakah pada lembaga amil zakat infak dan shodaqoh muhammadiyah (LAZISMU) Kabupaten Malang:

Harapannya penelitian ini dapat memberikan hasil evaluasi dan rekomendasi atas penerapan akuntansi zakat pada LAZISMU untuk dapat digunakan dalam rangka perbaikan pada periode selanjutnya. Selain itu, diharapkan dapat memberikan pengetahuan kepada masyarakat terkait informasi keuangan zakat sehingga masayarakat akan lebih percaya kepada lembaga amil zakat yang bersang- 
kutan. Serta dapat dijadikan sebagai referensi oleh peneliti-peneliti selanjutnya untuk perkembangan akuntansi secara umum.

\section{METODE PENELITIAN}

Penelitian ini merupakan penelitian deskriptif Kualitatif bersifat studi kasus. Adapun jenis data yang digunakan dalam penelitian ini yaitu data penerimaan dan pengeluaran dana Zakat, Infak dan sedekah serta laporan keuangan LAZISMU kabupaten Malang. Data tersebut diperoleh secara dokumentasi yaitu pengumpulan data dari dokumen-dokumen instansi yang relevan dengan masalah pokok penelitian dan dengan wawancara yaitu peneliti melakukan tanya jawab secara langsung kepada pengurus/karyawan atau pimpinan LAZISMU Kabupaten Malang berkenaan dengan pembahasan penelitian ini.

Teknik analisis data yang dilakukan dalam penelitian ini melalui beberapa tahapan yaitu mendeskripsikan gambaran akuntansi dana zakat dan infak/sedekah di LAZISMU kabupaten Malang,menganalisis pengukuran dana zakat dan infak/ sedekah di LAZISMU Kabupaten Malang, menganalisis pencatatan/pengakuan dana zakat dan infak/sedekah di LAZISMU Kabupaten Malang yang meliputi analisis pencatatan dan pengakuan penerimaan dan penyaluran dana ZIS, menganalisis penyaluran dana zakat dan infak/sedekah di LAZISMU Kabupaten Malang yang mencakup sasaran penyaluran dan jumlah yang disalurkan, menganalisis penyajian dana zakat dan infak/sedekah di LAZISMU Kabupaten Malang yang mencakup penyajian laporan dana ZIS, menganalisis pengungkapan dana zakat dan infak/sedekah di LAZISMU Kabupaten Malang., serta membandingkan akuntansi zakat LAZISMU dengan PSAK 109 untuk menyimpulkan kesesuaian penerapannya

\section{HASIL DAN PEMBAHASAN}

\section{Akuntansi Zakat pada LAZISMU Kabupaten Malang}

LAZISMU Kabupaten Malang telah menerapkan pencatatan secara lengkap terhadap setiap penerimaan dan zakat, infak, shdaqah, maupun yang lainnya. Sistem pencatatan di LAZISMU menggunakan single entry system yaitu pencatatan buku tunggal. Adapun prosedur pencatatan penerimaan dana adalah sebagai berikut:

1. Donatur atau muzzaki dapat datang sendiri ke LAZISMU, didatangi, atau mengirim via bank untuk melakukan pembayaran zakat atau infak.

2. Staf keuangan LAZISMU memberikan bukti pembayaran berupa kwitansi

3. Kemudian mencatatnya dalam buku penerimaan dana. Buku ini mencatat semua dana yang diterima baik dana zakat, tabungan haji, infak, dan lain sebaginya. Pecatatan ini meliputi: (1)Nama Donatur (2)Alamat (3)Jumlah Dana (4)Tujuan Pembayaran.

4. Catatan buku penerimaan tersebut kemudian direkap di komputer dengan memisahkan jenis dana yang diterima. Misalnya dana zakat mal, infak, tabungan Qurban, qurban, dan lain-lain berdasarkan buku catatan tersebut.

5. Setiap ada pembayaran maka bertambahlah saldo dana ZIS yang ada di LAZISMU.

6. Setiap bulan staf keuangan akan membuat laporan akhir bulan berdasarakan total penerimaan dikurangi penyaluran dan pengeluaran pada bulan yang bersangkutan. 
Analisis

Penerapan

Akuntansi...

754
Adapun prosedur penyaluran dana ZIS sebagai berikut:

1. Setiap akan dikeluarkannya dana, staf keuangan menyiapkan catatan pengeluaran pada buku pengeluaran yang terpisah dari buku penerimaan dan ditulis bearpa dana yang dikeluarkan, untuk disalurkan kemana, dan siapa penanggungjawabnya.

2. Setelah itu dana diserahkan kepada yang bertanggungjawab untuk disalurkan sesuai dengan program yang ada.

3. Setelah adanya pengeluaran maka berkurangnya saldo dana ZIS dan kemudian dilaporkan pada akhir bulan yang bersangkutan.

Macam-macam akun dana ZIS pada LAZISMU Kabupaten Malang:

1. Zakat Maal, merupakan dana zakat berupa harta yang dibayarkan kepada LAZISMU yang umumnya dalam bentuk kas. Dana zakat maal ini masuk dalam rekening zakat maal yang disajikan dalam laporan pemasukan donatur via-non rekening.

2. Infaq merupakan dana donatur yang diterima oleh LAZISMU sebagai dana kemanusiaan non-zakat yang kemudian disalurkan oleh LAZISMU melaui program-program rutin maupun insidental.

3. TABUR merupakan dana titipan masyarakat sebagai tabungan yang dicicil untuk persiapan qurban.

4. Zakat Fitrah merupakan zakat dalam bentuk makanan pokok yang disalurkan melalui LAZISMU baik LAZISMU kabupaten maupun jejaring yang ada di kecamatan. Zakat fitrah ini diterima pada bulan ramadhan begitu juga penyalurannya.

\section{Pengukuran Dana Zakat dan Infak/Sedekah}

Penerimaan zakat dalam LAZISMU selama ini didominasi oleh zakat dalam bentuk kas. Zakat non kas hanya dibayarkan oleh Muzzaki dalam bentuk zakat fitrah yang dibayar pada bulan ramadhan saja. Sehingga sangat jarang bahkan selama ini tidak pernah ada penurunan nilai terhadap zakat atau infak non kas. Berikut hasil wawancara dengan staff LAZISMU:

"Zakat dan infak yang diterima oleh LAZISMU kebanyakan adalah zakat dalam bentuk kas. Karena sejauh ini belum ada yang membayar zakat maal dalam dalam bentuk nonkas.Sehingga dana nonkas atau zakat dalam bentuk barang atau aset hanya terdapat pada zakat fitrah yang dibayarkan Muzzaki dan sekaligus disalurkan pada bulan ramadhan." tercantum dalam Lampiran 2 (jawaban Wawancara No.7)

Menurut PSAK No 109 jika terjadi penurunan nilai aset zakat nonkas, jumlah kerugian yang ditanggung harus diperlakukan sebagai pengurang dana zakat atau pengurang dana amil tergantung dari sebab terjadinya kerugian tersebut. Penurunan nilai aset diakui sebagai pengurang dana zakat jika terjadi tidak disebabkan oleh kelalaian amil; kerugian dan pengurang dana amil jika disebabkan oleh kelalaian amil.

Pengukuran yang dilakukan LAZISMU Kabupaten Malang mengenai penurunan zakat aset nonkas masih belum pernah ada pengukuran hal ini disebabkan belum adanya muzakki yang membayar zakat berupa aset non kas kecuali zakat fitrah. Zakat fitrah selama ini juga tidak ada penurunan nilai karena setelah diterima tidak lama segera disalurkan. Dalam hal ini proses pengukuran yang dilakukan oleh LAZISMU Kabupaten Malang masih belum bisa menyesuaikan dengan PSAK No 109 karena tidak ada pembayaran zakat non kas atau asset zakat non kas. Namun demikian, segala bentuk pengurangan sado dana karena penyaluran zakat dan pengeluaran operasional atas infak telah diakui dan terukur secara jelas. 
Dana Zakat diakui pada saat kas atau asset lainnya diterima. Dana yang diterima dari muzakki diakui sebagai penambah dana zakat jika dalam bentuk kas maka sebesar jumlah yang diterima, jika dalam bentuk nonkas maka sebesar nilai wajar asset nonkas tersebut. Namun yang lebih mendominasi penerimaan zakat dan infak/sedekah pada LAZISMU Kabupaten Malang adalah zakat dalam bentuk kas. Zakat dalam bentuk nonkas hanya berupa zakat fitrah yang diterima pada bulan ramadhan.

Dana Infak/sedekah yang diterima diakui sebagai dana infak/sedekah sebesar: (a) jumlah yang diterima, jika dalam bentuk kas; (b) nilai wajar, jika dalam bentuk nonkas. Infak/sedekah yang diterima diakui sebagai dana non amil yaitu diakui sebagai penambah dana ZIS.

Hal ini berdasarkan hasil wawancara dengan staf LAZISMU yang tercantum dalam Lampiran 2 (jawaban Wawancara No.5) menyatakan:

"Ketika ada yang membayar dana zakat, infak, maupun dana yang lain langsung dicatat dalam buku pennerimaan. Catatan tersebut mencamtumkan Nama Muzakki, Alamat, Jumlah Dana yang dibayarkan dan Untuk tujuan apa dana tersebut dibayarkan kemudian catatan dalam buku penerimaan tersebut direkap kembali dalam komputer sehingga menambah saldo masingmasing dana baik zakat, infak, maupun dana TABUR."

Ketika Muzzaki atau donatur bernama Trisakti Handayani warga Perumahan Bumiasin, melakukan pembayaran sebesar Rp 50.000, 00 untuk membayar infak maka akan dicatat dalam buku penerimaan sebagi berikut:

$\begin{array}{ll}\text { Nama } & \text { : Trisakti Handayani } \\ \text { Alamat } & \text { : Perumahan Bumiasin } \\ \text { Jumlah Dana } & \text { : Rp 50.000, } 00 \\ \text { Tujuan Pembayaran } & \text { : infak }\end{array}$

Selama ini pencatatan di LAZISMU tidak ada jurnal, namun saat terjadi penerimaan zakat dan infak pencatatannya sepert diatas. Menurut PSAK 109 ketika terjadi penerimaan zakat atau infak maka LAZ harus mencatatnya dalam bentuk jurnal sebagai berikut:

$\begin{array}{llr}\text { Dr. Kas-Dana Infak } & \text { Rp. } & 50.000,00 \\ \text { Kr. Dana Infak } & \text { Rp. } & 44.000,00 \\ \text { Kr.Dana Amil (12\%) } & \text { Rp. } & 6.000,00\end{array}$

Namun, karena di LAZISMU tidak dana amil maka seluruhnya dana yang diterima dari Trisakti Handayani diakui sebagai infak, adapun rekomendasi jurnal pencatatnnya adalah:

$\begin{array}{ll}\text { Dr. Kas-Dana Infak } & \text { Rp. } 50.000,00 \\ \text { Kr. Dana Infak } & \text { Rp. } 50.000,00\end{array}$

Menurut PSAK 109 yang berkaitan dengan penerimaan zakat, zakat yang diterima dari muzakki diakui sebagai penambah dana zakat jika dalam bentuk kas maka sebesar jumlah yang diterima dan jika dalam bentuk nonkas maka sebesar nilai wajar aset nonkas tersebut. Zakat yang diterima diakui sebagai dana amil untuk bagian amil dan dana zakat untuk dana zakat untuk bagian non amil. Jika muzakki menentukan mustahiq, maka seluruhnya menambah dana zakat, amil mendapatkan ujrah.

LAZISMU mengakui seluruh dana zakat dan infak yang diterima seluruhnya sebagai dana zakat atau infak, dalam hal ini tidak ada dana amil. Dana zakat seluruhnya diakui sebagai dana zakat dan disalurkan kepada 8 asnaf termasuk 
Analisis

Penerapan

Akuntansi...

756

amil berupa gaji amil. Diakuinya dana zakat sebagai tanpa menggolongkannya sebagai dana amil ini salah satu bentuk dari prinsip maslahah dan keikhlasan. Karena dana zakat adalah sepenuhnya dana umat sehingga dikhawatirkan terlalu banyak porsinya jika LAZIS harus memisahkan dana amil dan dana non amil atas dana zakat.

Dana infak diakui sebagai dana infak dan sewaktu-waktu disalurkan untuk melengkapi dana zakat dan sebagian digunakan sebagai biaya operasional LAZIS namun jumlahnya tidak tetap. Terkait permintaan Muzzaki untuk penyaluran kepada mustahiq tertentu, LAZISMU juga tidak mengambil ujrah untuk amil. Sedangkan menurut PSAK hal ini harus disisihkan untuk ujrah amil. Namun praktek di LAZISMU tidak mengambil ujrah amil atas penyaluran khusus tersebut. Karena ujrah amil sudah termasuk dalam pembagian 8 asnaf. Dengan demikian pengakuan dana zakat dan infak LAZISMU sesuai dengan PSAK 109 karena sudah ada pencatatan lengkap dan pemisahan saldo dana zakat, infak, dan lain-lain.

\section{Penyaluran Dana Zakat dan Infak/Sedekah}

Penyaluran dana zakat dan infak mengurangi dana zakat dan infak sebesar nilai yang disalurkan. Jumlah yang disalurkan sudah dianggarkan untuk program penyaluran rutin. Penyaluran ini telah sesuai dengan PSAK Menurut PSAK 109 penyaluran dana Zakat dan Infak/sedekah Penyaluran zakat mengurangi dana zakat dan infak sebesar nilai yang disalurkan.

LAZISMU menyalurkan zakat dan infak melalui dua jalur, jalur pertama melalui kegiatan-kegiatan yang telah terprogram secara rutin. Terkait target penyaluran dana ZIS, LAZISMU telah melaksanakan penyaluran zakat sesuai dengan 8 asnaf. Antara lain: keluarga fakir, miskin, Beasiswa Sekolah, Panti Asuan, Bantuan Sekolah, Bantuan guru dan ustad/ustadzah, dana Fiisabilillah PDM, Dana Kesehatan, dan lain-lain. Penyaluran ini melalui program rutin. Sedangkan jalur kedua melalui penyaluran secara insidental atau sewaktu-waktu sesuai dengan kebutuhan seperti ketika ada musibah, kecelakaan, bencana alam, dan lain-lain.

Berdasarkan wawancara dengan Staf bagian penyaluran di LAZISMU yang mengatakan:

"Penyaluran biasanya dilaksanakan dengan program-program rutin seperti program kesehatan, beasiswa sekolah, santunan panti, dan lain-lain. Selain itu penyaluran juga dilaksanakan sewaktu-waktu misalkan ketika da bencana alam, dan sebagainya." tercantum dalam Lampiran 2 (jawaban Wawancara No.8 kalimat ke 3)

Menurut PSAK 109, ketika terjadi penyaluran zakat maupun infak maka mengurangi saldo dana yang bersangkutan sebesar dana yang disalurkan. Misalkan ada penyaluran sebesar Rp. 250.000,00, hal ini dicatat dalam jurnal umum sebagai berikut:

Dr. Dana Zakat-Nonamil Rp. 250.000,00

Kr. Kas-dana zakat Rp. 250.000,00

Oleh sebab it LAZISMU hendaknya melakukan penjurnalan sebagai berikut: Dr. Dana Zakat Rp. 250.000,00

Kr. Kas-dana zakatRp.250.000,00

\section{Penyajian Dana Zakat}

Menurut PSAK 109, amil menyajikan dana zakat, dana infak/sedekah, dana amil, dan dana non halal secara terpisah dalam neraca (laporan posisi keuangan). Sedangkan LAZISMU Kabupaten Malang menyajikan dana zakat, dana infak/ sedekah, TABUR, dan lain-lain tidak dalam neraca namun disajikan secara terpisah dalam Laporan Pemasukan dan Pengeluaran Bulanan. 
PSAK 109 menyebutkan komponen laporan keuangan yang lengkap dari amil terdiri dari neraca (laporan posisi keuangan), laporan perubahan dana, laporan perubahan aset kelolaan, laporan arus kas dan catatan atas laporan keuaangan. Sedangkan LAZISMU mempunyai beberapa laporan keuangan diantaranya antara lain: Laporan Penerimaan/ Pemasukan Donatur, Laporan Pemasukan dan Pengeluaran Dana, Laporan Penitipan dan Penyaluran Zakat Fitrah, Laporan dan Tabungan Qurban

LAZISMU menyajikan dana zakat dan dana infak/ sedekah dalam laporan yang terpisah dalam beberapa komponen Laporan Keuangan seperti:

a. Laporan Penerimaan/ Pemasukan Donatur

Berupa laporan pemasukan dari donatur baik yang berupa zakat, infaq, maupun dana Tabungan Qurban. Laporan terdiri dari 6 kolom berupa kolom Nama Donatur, Alamat, 3 jenis dana, dan jumlah/total.

b. Laporan Pemasukan dan Pengeluaran Dana

Laporan pengeluaran ini mencantumkan jumlah dan sumber penerimaan dana, perincian pengeluaran dana, dan saldo penerimaan setelah dikurangi pengeluaran.

c. Laporan Penitipan dan Penyaluran Zakat Fitrah

Terdiri dari zakat fitrah berupa makanan pokok yang umumnya beras dan dana fidyah.

d. Laporan dan Tabungan Qurban

Laporan ini terdiri dari daftar nama donatur Tabungan Qurban yang terdiri dari tabungan (D) dan pengambilan (K)

\section{Pengungakapan Dana Zakat dan Infak/Sedekah}

LAZISMU mengungkapakan donatur baru, program-program jemput zakat dan infak serta program-program penyaluran zakat dalam buletin "MATAHATI" dan kalender kegiatan LAZISMU. Sementara untuk metode pengukuran serta presentase alokasi dana amil tidak dicantumkan atau dalam arti lain tidak diungkapkan. Menurut PSAK amil harus mengungkapkan beberapa hal terkait dana Zakat dan Infak baik berupa kebijakan penyaluran, Pembagian, telah diinformasikan dalam laporan bulanan LAZISMU. namun, beberapa hal misalnya penilaian nilai wajar, skala prioris, dan hubungan istimewa tidak diungkapkan. Sehingga pengungkapan dana zakat dan infak LAZISMU belum sesuai dengan PSAK 109.

\section{Menganalisis Kesesuaian Perlakuan Akuntansi Zakat dan Infak/sedekah LAZISMU berdasarkan PSAK 109}

Berdasarkan hasil analisis data dan pembahasan terkait Akuntansi Zakat dan Infak/sedekah mencerminkan bahwa secara keseluruhan perlakuan akuntansi Zakat dan Infak di LAZISMU Kabupaten Malang ada beberapa poin yang sudah sesuai dengan PSAK 109 yaitu pengakuan dan penyaluran. Namun, pengukuran, penyajian, dan pengungkapan Zakat dan Infak/sedekah belum sesuai dengan PSAK 109.

Hal ini disebabkan karena ada beberapa akun dan jenis zakat yang tidak terdapat di LAZISMU seperti zakat dalam bentuk non kas. Sehingga tidak ada penyusutan atau penurunan nilai. Selain itu LAZISMU juga tidak memisahkan dana zakat dan dana amil. Keseluruan dana yang diterima sebagai zakat diakui sebagi dana zakat tanpa menyisihkannya sebagai dana amil, sedangkan dana operasional diambil dari dana infak. Namun, tidak adanya pemisahan dana amil dan non amil terkait zakat ini sebenarnya tidak berdampak negatif terhadap akuntansi dana zakat justru mengantisipasi adanya kelebihan dana amil karena sejatinya dana zakat dan infak adalah milik umat. Secara etika, amil memang harus menggunakan dana ZIS untuk operasional dengan sewajarnya dan tidak boleh terlalu banyak porsinya. 
Analisis

Penerapan

Akuntansi...

758

Sejauh ini, permasalahan yang ada di LAZISMU Kabupaten Malang terkait penerapan PSAK 109 adalah pemahaman sumber daya manusia di LAZISMU Kabupaten Malang masih kurang, sehingga dalam melakukan pembukuannya hanya sebatas menggunakan sistem pencatatan sederhana yaitu dengan sistem single entry yang dianggap lebih mudah untuk dilakukan serta mudah dipahami sehingga laporan Keuangan yang disusun belum sesuai dengan PSAK 109.

Ketidak pahaman ini dapat ditanggulangi salah satu nya dengan sosialisasi pemerintah dan pembinaan secara langsung terkait Akuntansi yang sesuai PSAK 109. Sehingga ketika setiap LAZIS sudah dipahamkan pelaksanaan akuntansi ZIS sesuai PSAK 109 ini dapat diwajibkan untuk diberlakukan oleh semua LAZIS sehingga pengelolaan zakat secara nasional dapat informative dan akuntabel.

\section{SIMPULAN}

Berdasarkan hasil analisis data dan pembahasan terkait Akuntansi Zakat dan Infak/sedekah mencerminkan bahwa perlakuan akuntansi Zakat dan Infak di LAZISMU Kabupaten Malang ada beberapa poin yang sudah sesuai dengan PSAK 109 yaitu pengakuan dan penyaluran. Namun, pengukuran, penyajian, dan pengungkapan Zakat dan Infak/sedekah belum sesuai dengan PSAK 109. Selain itu LAZISMU juga tidak memisahkan dana zakat dan dana amil, dimana keseluruan dana yang diterima sebagai zakat diakui sebagai dana zakat tanpa menyisihkannya sebagai dana amil, sedangkan dana operasional diambil dari dana infak.

Hasil penelitian ini dapat dijadikan sebagai bahan masukan bagi LAZISMU Kabupaten Malang dan LAZIS di Indonesia agar dapat melakukan proses akuntansi mengacu dan sesuai pada, sehingga pengelolaan ZIS dapat dilaksanakan secara benar dan transparan serta informatif bagi masyarakat umum. Serta bagi pemerintah baik IAI, Baznas Pusat, atau dewan Syariah sebaiknya mengadakan pelatihan untuk seluruh OPZ Indonesia terkait praktik penerapan Akuntansi Zakat dan Infak/sedekah sesuai dengan PSAK 109 kemudian mewajibkan kepada semua OPZ untuk mengelola dana zakat dan infak sesuai dengan PSAk 109 tersebut.

\section{DAFTAR PUSTAKA}

Al-Quranul Karim

BAZNAS. 2015. "Penerimaan dan Penyaluran Tahun 2015”. Baznas.

Handoko, E.E. 2013. "Analisis Penerapan Akuntansi Zakat Dan Infak/Sedekah (Psak 109) Pada Yayasan Dompet Dhuafa Republika”. Laporan Magang Universitas Indonesia. Depok

IAI. 2011. “Pernyataan Standar Akuntansi Keuangan 109'. DSAK. Jakarta

Istutik. 2013. "Analisis Implementasi Akuntansi Zakat dan infak/Sedekah (Psak:109) Pada Lembaga Amil Zakat di Kota Malang”. Jurnal Akuntansi Aktual. Vol. 2 No. 1. hlm. 19-24.

Info Jambi "Ini Dia Jumlah Muslimdi Sejumlah Negara" http://infojambi.com/ internasional/6911-ini-dia-jumlah-muslim-di-sejumlah-negara.html

Kanji, L. and A.H. Habbe. 2011. "Determinan Motivasi Membayar Zakat". Jurnal UNHAS.

Mu'is, F. 2011. "Zakat A-Z Panduan Mudah, Lengkap, dan Praktis tentang zakat”. Tinta Medina. Solo.

Nikmatuniayah. 2012. "Akuntabilitas Laporan Keuangan Organisasi Pengelola Zakat Yayasan Daruttaqwa Semarang". Prosiding SN Penelitian dan PKM. Vol. 3. No. 1. 